\title{
Factors determining presence of passerines breeding within White Stork Ciconia ciconia nests
}

\author{
Adam Zbyryt $^{1} \cdot$ Dariusz Jakubas $^{2} \cdot$ Marcin Tobolka $^{3}$
}

Received: 24 January 2017 /Revised: 5 June 2017 / Accepted: 24 July 2017 / Published online: 18 August 2017

(C) The Author(s) 2017. This article is an open access publication

\begin{abstract}
Nests of White Stork Ciconia ciconia are commonly used by various passerines as nesting sites. In this study, we investigated factors determining presence and number of pairs of species breeding within White Stork nests in an extensive farmland in NE Poland. In 133 (57\%) out of 233 White Stork nests, we found at least one breeding pair of passerine bird. These were from three species: House Sparrows Passer domesticus (68\% of 133 nests with co-breeding), Tree Sparrows Passer montanus (65\%), and Starlings Sturnus vulgaris $(30 \%)$. The probability of breeding passerines within White Stork nests increased with increasing nest thickness, and was significantly higher in currently occupied nests. Sparrows were more likely to breed in White Stork nests located on electricity poles, situated closer to settlements and surrounded mainly by arable fields where meadows were not prevalent. In this paper, we show that White Stork nests are favorable nesting sites for passerines, as they are well insulated and provide an anti-predatory shield.
\end{abstract}

Keywords Nest · Breeding ecology · Nesting site selection · Communal breeding $\cdot$ Predator protection

Communicated by: Pamela C. Rasmussen

Marcin Tobolka

tobolkamarcin@gmail.com

1 The Polish Society for Birds Protection (PTOP), Ciepła 17, 15-471 Białystok, Poland

2 Department of Vertebrate Ecology and Zoology, University of Gdańsk, Wita Stwosza 59, 80-308 Gdańsk, Poland

3 Institute of Zoology, Poznań University of Life Sciences, Wojska Polskiego 71C, 60-625 Poznań, Poland

\section{Introduction}

Many bird species are known to nest in assemblages of several pairs of the same or different species. Over $10 \%$ of avian species including gulls Laridae, auks Alcidae, waders Charadrii, some raptors Accipitriformes, and many passerines Passeriformes breed colonially (Gill 2007). This has several advantages such as increased predator detection (e.g., Elgar 1989), communal defense (e.g., Stenhouse et al. 2005; Jungwirth et al. 2015), and facilitated foraging (e.g., Møller 1987; Richner and Heeb 1995). However, it brings several costs due to stress and aggressive behavior (e.g., Saino 1994; Nicol et al. 1999) or parasite transfer (e.g., Valera et al. 2003).

One form of communal breeding is when smaller birds, for example, passerines, breed in the nests of bigger species. According to the "predator protection" hypothesis (Koskimies 1957), using the nests of other, bigger species may provide passerines with better protection from predators compared to individual breeding sites. Co-breeding species nesting near protective associates gain reproductive success benefits. More aggressive species or individuals are often chosen as a neighbor (Quinn and Ueta 2008). However, breeding in predators' nests may be disadvantageous for small passerines. Some opportunistic predators prey on passerine chicks (Jaksić and Braker 1983). A particular case of colonial nesting is the co-breeding of passerines in White Stork (WS) Ciconia ciconia nests. In Europe, House Sparrow Passer domesticus, Tree Sparrow P. montanus, and Starling Sturnus vulgaris are the most common WS co-breeders (Indykiewicz 2006). The WS nest provides good shelter from precipitation, low temperatures, and wind for passerines and is available during the breeding (Indykiewicz 1998, 2006; Bocheński 2005; Kosicki et al. 2007) and wintering seasons (Tobolka 2007, 2011). On the other hand, the exposed location of the WS nests (on electricity poles, high chimneys, and the tops of buildings) increases predation risk (e.g., by the Sparrowhawk 
Accipiter nisus) during flight to/from the nest when it is used as a roosting site (Tobolka 2007, 2011). What is more, the WS may be a potential predator of residents as it is an opportunistic predator and it has been documented that passerine birds may be included in its diet (Kosicki et al. 2006; Chenchouni 2016). However, predation in the case of associated nesting occurs rarely. In Algeria, only a few cases of WS predation on sparrows within WS nests have been recorded (Chenchouni, personal information). Co-breeding with larger species may affect the behavior of the protected species. Savannah sparrows Passerculus sandwichensis nesting far from gull Larus spp. colonies were much more cautious while returning to their nests and perched on vegetation nearby for $20 \%$ longer before entering the nest compared to individuals breeding in gull colonies (Wheelwright et al. 1997).

Populations of Tree Sparrow and House Sparrow are currently declining in many European countries (Mitschke et al. 2000; Hole et al. 2002; Summers-Smith 2003, 2005; Robinson et al. 2005; Shaw et al. 2008), including Poland (Chylarecki and Jawińska 2007). Decreased nesting site availability, due to restoration of buildings and thermo-modernization limiting access to potential nesting sites, is considered as one of the most important factors causing population decline (Crick et al. 2002). In this context, WS nests additionally providing higher antipredatory protection may be perceived as favorable breeding/ roosting sites for passerines (Indykiewicz 1998, 2006; Tobolka 2011). So far, only a few papers have focused on the breeding of passerines within WS nests. Most of them are simply of a descriptive nature (e.g., Indykiewicz 1998, 2006; Bocheński 2005; Tobolka 2007, 2011) or investigate very simple and arbitrarily chosen factors determining the number of breeding pairs of Sparrows (e.g., Kosicki et al. 2007).

The aim of this study is to investigate factors determining presence/absence and number of species and pairs breeding within WS nests in an extensive farmland in NE Poland. We examine whether the presence/number of pairs of passerines breeding within WS nests is determined by WS nest thickness or nest location (electricity pole or other location). We hypothesize that thicker WS nests may accommodate more passerines. We expect that WS nests located on electricity poles attract more co-breeding passerines. One may expect that thicker nests may accommodate more co-breeding passerines. However, this hypothesis has not been confirmed (e.g., Kosicki et al. 2007; Tobolka 2011). Also, nest location may play an important role in passerine colonization of WS nests. Nests located on electricity poles are considered as safer from predators than to nests located on buildings or trees (Tryjanowski et al. 2009). Furthermore, we examine whether the number of breeding passerine pairs was affected by the main habitats in surrounding areas. Sparrows breeding close to human settlements usually forage in open agricultural areas like arable land, meadows, or set-asides (Shaw et al. 2008); therefore, we predict that the number of Sparrows and
Starlings breeding in WS nests depends on the habitat structure in the vicinity of the nest. Due to possible inter-species competition between House and Tree Sparrows sharing the same foraging and nesting niches (Cordero and RodriguezTeijeiro 1990), we expect that those species will avoid conesting, which has been also shown in an urban environment (e.g., Wegrzynowicz 2012).

\section{Materials and methods}

\section{Study area}

The study was carried out in NE Poland, in the North Podlasie Lowland $\left(21^{\circ} 51^{\prime}-23^{\circ} 57^{\prime} \mathrm{E} ; 52^{\circ} 17^{\prime}-53^{\circ} 54^{\prime} \mathrm{N}\right)$ within four mesoregions: Biebrza Basin, Białystok Heights, Bielsk Plain, and Upper Narew Valley covering $9440 \mathrm{~km}^{2}$ (Kondracki 2013). The postglacial landscape of North Podlasie Lowland is characterized by gently roughened relief, strongly transfigured by the denudation processes. These mesoregions are one of the least populated in Poland. The landscape is dominated by agricultural land which occupies ca. $60 \%$, forests cover ca. $30 \%$, while urban areas constitute less than $5 \%$. The largest urban centre is Białystok (195,000 citizens). Farmland dominates the landscape of the studied area with arable lands making up ca. $60 \%$, meadows ca. $30 \%$, and pastures ca. $6 \%$ of total utilized agricultural area (Statistical Office 2016). This area is classified as a region dominated by intensive farming (Chylarecki et al. 2006) with dominance of small farms (up to 10 ha) with extensive agriculture use.

\section{Fieldwork}

To collect data on the presence and numbers of cobreeding bird species, we surveyed in total 133 and 90 nests of WS occupied and unoccupied by passerines, respectively (in that 80 and 38 in 2014 and 53 and 52 in 2015, respectively). We studied different nests in both study years. The area selected for the study is characterized by the highest WS density in Poland (density of breeding pairs more than 40 pairs per $100 \mathrm{~km}^{2}$ ). The majority of WS nests in the North Podlasie Lowland are located on electricity poles (>50\%). In contrast to other parts of the country, the share of nests on roofs is still high constituting $30 \%$ (Guziak and Jakubiec 2006).

We collected data in the first and second weeks of May, i.e., during the period of intense feeding of the young. We surveyed all nests only once. During the survey, we spent ca. $20 \mathrm{~min}$ (range 20-50 $\mathrm{min}$ ) at each WS nest collecting data on nest status (occupied/not occupied by WS) and co-breeding species status (presence/absence, species, and number of pairs). 
For each surveyed WS nest, we also collected the following set of variables: main type of agriculture within the radius of $500 \mathrm{~m}$ around the nest (classified as pasture, meadow, or arable land when that habitat covered $>75 \%$ of area), type of the nest location (electricity pole, roof, or tree), distance to the nearest building, nest thickness (the height of the nest construction), and nest occupation status (occupied or not by WS). Nest thickness was estimated with $10 \mathrm{~cm}$ accuracy by visual comparison with the width of the platform under WS nest $(120 \mathrm{~cm}$ ), the bricks of the chimney (width of $25 \mathrm{~cm}$ ), and other electricity pole characteristics.

\section{Statistical analyses}

To analyze factors determining presence/absence of avian species breeding within WS nests in NE Poland, we used logistic regression. To analyze factors affecting number of species and pairs breeding in WS nests, we used multiple ordinary least square (OLS) regression. Predictors used in all analyses are described in Table 1. Firstly, we analyzed presence/absence of any co-breeding passerine species. Then, we performed analyses only for WS nests with other avian species breeding within, separately for Starling, House Sparrow, and Tree Sparrow. For those uni-species models, we performed analyses in two steps: firstly, with a predictor describing presence/absence of any other co-breeding passerines (i.e., SAlien for Starling, HSAlien for House Sparrow, and TSAlien for Tree Sparrow) to recognize if the effect of any co-breeding species is important for the focal species. If this predictor was important, we performed an additional analysis with separate predictors indicating presence/ absence of the particular co-breeding species (i.e., SPres, HSPres, TSPres) to recognize if the presence of a particular species is important for the focal species.

We assessed whether the data sufficiently met the assumptions of the linear model using Q-Q plots (quantile expected in normal distribution vs quantile observed for residuals). We normalized data on DisClosWS, DisBuild, and NestThick using the $\ln$ transformations. All analyzed predictors were non-collinear (Pearson correlation coefficients, $r<|0.15|$ ).

We selected the best logistic and OLS regression models using Akaike's information criterion for small sample sizes $\left(\mathrm{AIC}_{\mathrm{c}}\right.$ ) (Burnham and Anderson 2002; Hegyi and Garamszegi 2011). We compared the relative performance of the models based on $\triangle \mathrm{AIC}_{\mathrm{c}}$, i.e., difference between the AIC value of the best model and the AIC value for each of the other models (Burnham and Anderson 2002). We presented only models with $\triangle \mathrm{AICc} \leq 1$, suggested to be within the range of plausible models to best fit the observed data (Burnham and Anderson 2002).

The significance of the OLS regression models was checked using Wald statistics. To evaluate the discriminatory performance of logistic regression models, we used the receiver operating characteristic function (AUC) (Pearce and Ferrier
2000). Our criteria for the predictive capability were based on the AUC value. We considered logistic regression models with AUC $\geq 0.7$ as good models and $<0.7$ as poor models (Hosmer et al. 2013). We presented only OLS regression models with at least one significant $(p>0.05)$ predictor.

We performed all statistical analysis in R software ( $R$ Development Core Team 2015) with MuMin (Bartoń 2013), aod (Lesnoff and Lancelot 2012), and pROC (Robin et al. 2011) packages.

\section{Results}

\section{Frequency of nesting passerines within White Stork nests}

In 133 White Stork nests (57\% of all surveyed), we found at least one of three co-breeding passerine species, i.e., House Sparrows (68\% of all nests with co-breeding), Tree Sparrows $(65 \%)$, and Starlings (30\%). Breeding frequency differed significantly between them $\left(\chi_{2}^{2}=15.74, p<0.001\right)$. The proportion of WS nests with House Sparrows was similar to that with Tree Sparrows $\left(\chi_{1}^{2}=0.054, p=0.82\right)$. Starlings nested in WS nests, less frequently than House Sparrows $\left(\chi_{1}^{2}=13.5\right.$, $p=0.0002)$ or Tree Sparrows $\left(\chi_{1}^{2}=11.9, p=0.0005\right)$. We found nesting of more than one species in $51 \%$ of the WS nests with co-breeding passerines. Some WS nests were occupied exclusively by only one passerine species (33\% of WS nests with Starlings, $32 \%$ of nests with House Sparrows, and $49 \%$ of nests with Tree Sparrows).

\section{Factors determining presence/absence of avian species breeding within White Storks nests}

For all passerine species combined, we found two logistic regression models describing the factors affecting the presence/absence of co-breeding within WS nests (Table 2). In both models, the probability of breeding passerines within WS nests increased with increasing nest thickness, and was significantly higher in nests currently occupied by WS, situated on electricity poles, and characterized by low prevalence of meadows in the vicinity. Additionally, according to the second candidate model [with higher predictive capability $(\mathrm{AUC}=0.78)$ compared to the first one $(\mathrm{AUC}=0.71)]$, presence of co-breeders was more likely in nests situated closer to buildings (Table 2).

Then, we performed separate analyses for particular cobreeding species. For the Starling, we found two models describing the factors affecting breeding within WS nests. According to the first model, the probability of presence of Starlings increased with increasing nest thickness. However, its predictive capability was low $(\mathrm{AUC}=0.57)$. The second model includes only an intercept (Table 2). 
Table 1 Variables used in logistic and OLS multiple regression analyses (LR and OLSR, respectively)

\begin{tabular}{|c|c|c|c|}
\hline Code & Variable & Comments & Analysis \\
\hline AvPres & $\begin{array}{l}\text { Presence of any avian species breeding in WS } \\
\text { nest }\end{array}$ & $0 / 1$-absence/presence & LR \\
\hline Arable & $\begin{array}{l}\text { Prevalence of arable land within the radius of } \\
500 \mathrm{~m} \text { of WS nest }\end{array}$ & $0 / 1$-false/true & $\begin{array}{l}\text { LR, } \\
\quad \text { OLS- } \\
\text { R }\end{array}$ \\
\hline Mead & $\begin{array}{l}\text { Prevalence of meadows within the radius of } \\
500 \mathrm{~m} \text { of WS nest }\end{array}$ & $0 / 1$-false/true & $\begin{array}{l}\text { LR, } \\
\text { OLS- } \\
\text { R }\end{array}$ \\
\hline Pole & Nest situation on the pole & $0 / 1$-false/true & OLSR \\
\hline WSPres & WS nest status & 0/1-unoccupied/occupied & $\begin{array}{l}\text { OLSR, } \\
\text { LR }\end{array}$ \\
\hline DisClosWS & Distance to the nearest WS nest & In meters & $\begin{array}{l}\text { LR, } \\
\text { OLS- } \\
\text { R }\end{array}$ \\
\hline DisBuild & Distance to the nearest building & In meters & $\begin{array}{l}\text { LR, } \\
\quad \text { OLS- } \\
\text { R }\end{array}$ \\
\hline NestThick & Nest thickness & $\begin{array}{l}\text { Expressed by its height (in } \\
\text { centimeters) }\end{array}$ & $\begin{array}{l}\text { LR, } \\
\quad \text { OLS- } \\
\text { R }\end{array}$ \\
\hline NoSpec & No. of species breeding in WS nest & - & OLSR \\
\hline TotNoPair & Total no. of pairs of breeding in WS nest & All species combined & OLSR \\
\hline SPair & No. of Starling pairs breeding in WS nest & - & OLSR \\
\hline HSPair & $\begin{array}{l}\text { No. of House Sparrow pairs breeding in WS } \\
\text { nest }\end{array}$ & - & OLSR \\
\hline TSPair & No. of Tree Sparrow pairs in WS nest & - & OLSR \\
\hline SPres & Presence of Starling breeding in WS nest & $0 / 1$ - absence/presence & LR \\
\hline HSPres & $\begin{array}{l}\text { Presence of House Sparrow breeding in WS } \\
\text { nest }\end{array}$ & $0 / 1$-absence/presence & LR \\
\hline TSPres & Presence of Tree Sparrow breeding in WS nest & $0 / 1$ - absence/presence & LR \\
\hline SAlien & $\begin{array}{l}\text { Presence of species other than Starling in WS } \\
\text { nest }\end{array}$ & $\begin{array}{l}0 / 1 \text { —absence/presence of HS and } \\
\text { TS combined }\end{array}$ & OLSR \\
\hline HSAlien & $\begin{array}{l}\text { Presence of species other than House Sparrow } \\
\text { in WS nest }\end{array}$ & $\begin{array}{l}\text { 0/1—absence/presence of } \mathrm{S} \text { and } \\
\mathrm{TS} \text { combined }\end{array}$ & OLSR \\
\hline TSAlien & $\begin{array}{l}\text { Presence of species other than Tree Sparrow in } \\
\text { WS nest }\end{array}$ & $\begin{array}{l}0 / 1 \text { - absence/presence of } \mathrm{S} \text { and } \\
\text { HS combined }\end{array}$ & OLSR \\
\hline
\end{tabular}

WS White Stork
For the House Sparrow, we found four models describing the factors affecting their breeding within WS nests (Table 2). In the fourth model [with the highest predictive capability $(A U C=0.74)$ ], the probability of presence of House Sparrows was higher in WS nests situated in areas where meadows are not prevalent (92\% of nests), closer to buildings, without breeding Tree Sparrows, without Starlings (however, this effect was not significant, $p=0.25$ ), and situated on electricity poles (68\% of nests) (Table 2).

For the Tree Sparrow, we found four models describing factors affecting their breeding within WS nests (Table 2). According to the model with highest predictive capability $(\mathrm{AUC}=0.55)$, the probability of presence of Tree Sparrows was higher in WS nests without co-breeding House Sparrows, and situated in areas with high prevalence of meadows, located further from buildings. However, prevalence of meadows and distance from buildings were not significant $(p=0.139$, $p=0.288)$ (Table 3).

\section{Factors affecting numbers of species and pairs breeding within White Stork nests}

All OLS regression models investigating factors affecting the number of species breeding within WS nests were characterized by very low determination coefficients (adjusted $R^{2}<0.01$ ). According to the best OLS regression model determining factors affecting the total number of co-breeding pairs (adjusted $R^{2}=0.11$ ), their number was higher in areas surrounded by arable land, in thicker nests, nests situated closer to buildings, and nests on electricity poles (Table 4).

Then, we performed separate models for particular cobreeding species. For the Starling, we found three models 
Table 2 Rank of the best logistic regression models for factors determining presence/absence of species breeding within White Storks nests in NE Poland based on Akaike's information criterion corrected for small sample size $\left(\mathrm{AIC}_{\mathrm{c}}\right)$

\begin{tabular}{|c|c|c|c|c|c|}
\hline $\begin{array}{l}\text { Model } \\
\text { type }\end{array}$ & Model parameters & $\mathrm{AIC}_{\mathrm{c}}$ & $\Delta \mathrm{AIC}_{\mathrm{c}}$ & $\begin{array}{l}\text { Akaike's } \\
\text { weights }\end{array}$ & AUC \\
\hline FM & \multicolumn{5}{|c|}{ AvPres $\sim$ arab + mead + pole + WSPres + DisBuild + NestThick + DisClosWS } \\
\hline \multirow[t]{2}{*}{ BMs } & $\begin{array}{l}- \text { Int }+ \text { NestThick }- \text { mead }- \text { DisBuild }+ \text { pole }+ \\
\text { WSPres }\end{array}$ & 210.5 & 0.00 & 0.373 & 0.71 \\
\hline & - Int + NestThick - mead + pole + WSPres & 211.7 & 1.20 & 0.205 & 0.78 \\
\hline FM & \multicolumn{5}{|c|}{$\begin{array}{l}\text { SPres } \sim \text { arab + mead + pole + WSPres + DisBuild + NestThick + NestSit + DisClosWS + } \\
\text { HSPres + TSPres }\end{array}$} \\
\hline \multirow[t]{2}{*}{ BMs } & - Int + NestThick & 164.6 & 0.00 & 0.239 & 0.57 \\
\hline & - Int & 164.7 & 0.13 & 0.224 & - \\
\hline FM & \multicolumn{5}{|c|}{$\begin{array}{l}\text { HSPres } \sim \text { arab + mead + pole + WSPres + DisBuild + NestThick + NestSit + DisClosWS + } \\
\text { SPres + TSPres }\end{array}$} \\
\hline \multirow[t]{4}{*}{ BMs } & Int - mead - BuildDis - TSPres + pole & 155.0 & 0.00 & 0.220 & 0.72 \\
\hline & Int + arab - mead - BuildDis - TSPres + pole & 155.0 & 0.02 & 0.217 & 0.70 \\
\hline & Int + arab - BuildDis - TSPres + pole & 155.4 & 0.44 & 0.176 & 0.68 \\
\hline & Int - mead - BuildDis - TSPres + pole - SPres & 155.9 & 0.89 & 0.141 & 0.74 \\
\hline FM & \multicolumn{5}{|c|}{$\begin{array}{l}\text { TSPres } \sim \text { arab + mead + pole + WSPres + DisBuild + NestThick + NestSit + DisClosWS + } \\
\text { HSPres + SPres }\end{array}$} \\
\hline \multirow[t]{4}{*}{$\mathrm{BMs}$} & Int + mead - HSPres & 165.6 & 0.00 & 0.239 & 0.44 \\
\hline & Int - HSPres & 166.2 & 0.64 & 0.174 & 0.37 \\
\hline & Int + mead - HSPres + pole & 166.3 & 0.68 & 0.170 & 0.48 \\
\hline & Int + mead - HSPres + DisBuild & 166.6 & 0.99 & 0.146 & 0.55 \\
\hline
\end{tabular}

Only the best models with $\triangle \mathrm{AIC}_{\mathrm{c}} \leq 1$ are presented; Akaike's weights are calculated from the full set of models. The predictive capability of functions based on area under the receiver operating characteristic function (AUC); good models (AUC $\geq 0.7$ ) bolded. Predictor codes: see Table 1

FM full model, BMs best models, Int intercept describing the factors affecting the number of pairs breeding within WS nests (Table 4). According to the best model (with the highest determination coefficient, adj. $R^{2}=0.11$ ), the number of breeding pairs was higher in thicker WS nests without any co-breeding passerines, situated further from the nearest WS nest, and where meadows are not prevalent. However, distance to nearest WS nest and prevalence of meadows were not insignificant $(p>0.08)$ (Table 5). When considering the presence/absence of particular co-breeding species, we found two models. In both models, the number of Starling pairs was higher in thicker WS nests $(p=0.02)$. According to the second model, number of pairs was also higher in nests situated on electricity poles; however, this effect was not significant $(p=0.23$ ) (Table 5). Both models were characterized by low determination coefficients (adj. $\left.R^{2}<0.04\right)$.

For the House Sparrow, we found one model describing the factors affecting the number of pairs breeding within WS nests (adj. $R^{2}=0.13$ ) (Table 4). The number of breeding pairs was higher in WS nests surrounded mainly by arable land (mean \pm SD $2.2 \pm 1.2$ pairs vs $1.2 \pm 1.3$ pairs), where meadows are not prevalent $(1.4 \pm 1.3$ pairs vs $0.6 \pm 0.8$ pairs), in WS nests situated closer to buildings, without co-breeding passerines $(1.8 \pm 1.1$ pairs vs $1.3 \pm 1.3$ pairs $)$, and situated on electricity poles $(1.3 \pm 1.3$ pairs vs $1.1 \pm 1.2$ pairs) (Table 5$)$. In the set of models including presence/absence of particular co-breeding species, the best model (adj. $R^{2}=0.15$ ) predicts that the probability of breeding House Sparrows is higher in WS nests surrounded mainly by arable land, where pastures are not prevalent, situated closer to buildings, without co-breeding Tree Sparrows, and situated on electricity poles (Table 5).

For the Tree Sparrow, we found two models describing the factors affecting the number of pairs breeding within WS nests (Table 4). In both models, the number of breeding pairs was higher in thicker WS nests, in areas surrounded by arable land (mean \pm SD $1.8 \pm 1.5$ pairs vs $1.0 \pm 1.1$ pairs in areas surrounded mainly by other habitats) and meadows (1.6 \pm 1.3 pairs vs $1.0 \pm 1.1$ pairs), and without co-breeding passerines ( $1.5 \pm 0.9$ pairs vs $1.0 \pm 1.2$ pairs). According to the first model, the number of pairs was also higher in nests situated on electricity poles (Table 5). However, both models were characterized by very low determination coefficients (adj. $R^{2}<0.09$ ). When considering the presence/absence of particular co-breeding species, we found three models. In all models, the number of breeding pairs was higher in thicker WS nests, located in areas surrounded by arable land and meadows. According to the second model, the number of pairs was also higher in nests situated on electricity poles, and according to the third model, in nests without co-breeding House Sparrows (Table 5). However, all models were characterized by negligible determination coefficients (adj. $\left.R^{2}<0.08\right)$. 
Table 3 The best logistic regression models for factors determining presence/absence of species breeding within White Storks nests in NE Poland

\begin{tabular}{lccc}
\hline Model parameters & $b$ & SE & $P$ \\
\hline All species combined (model 2, AUC $=0.779)$ & \\
Int & -9.09 & 1.93 & $<0.001$ \\
NestThick & 1.73 & 0.47 & $<0.001$ \\
Mead & -1.00 & 0.46 & 0.030 \\
Pole & 2.90 & 0.42 & $<0.001$ \\
WSPres & 1.69 & 0.45 & $<0.001$ \\
Starling (model1, AUC $=0.75)$ & & \\
Int & -3.61 & 1.90 & 0.057 \\
NestThick & 0.73 & 0.50 & 0.141 \\
House Sparrow (model 4; AUC & $0.742)$ & & \\
Int & 1.26 & 0.77 & 0.104 \\
Mead & -1.15 & 0.60 & 0.056 \\
DisBuild & -0.47 & 0.16 & 0.004 \\
TSPres & -1.24 & 0.50 & 0.013 \\
Pole & 1.95 & 0.96 & 0.043 \\
SPres & -0.51 & 0.45 & 0.253 \\
Tree Sparrow (model 4; AUC $=0.55)$ & & \\
Int & 1.13 & 0.50 & 0.025 \\
Mead & 1.18 & 0.80 & 0.139 \\
DisBuild & 0.12 & 0.11 & 0.288 \\
HSPres & -1.14 & 0.48 & 0.017 \\
\hline
\end{tabular}

Predictor codes: see Table 1

Int intercept

\section{Discussion}

This is the first study investigating factors affecting breeding of passerines within WS nests in NE Poland, i.e., in the optimal WS breeding area in Central Europe (Profus 2006), characterized by high breeding density (Guziak and Jakubiec 2006). So far, studies on co-breeding passerines were conducted in areas with low or very low WS density in W Poland (e.g., Indykiewicz 2006; Kosicki et al. 2007; Tobolka 2007, 2011).

\section{Factors determining presence and numbers of co-breeding passerines within White Stork nest}

We found that over $50 \%$ of the studied WS nests had cobreeding passerines. Breeding within WS nests has several advantages such as good thermal insulation (Pinowski et al. 2006) and anti-predator protection (Indykiewicz 2006). Our analyses revealed that the probability of breeding of any passerines within WS nests increased with increasing nest thickness and distance from the nearest building, and was higher in currently occupied nests and in areas where meadows are not prevalent. Our analyses indicate that nest occupancy by WS was an important factor, suggesting that its presence may be advantageous for co-breeding passerines. This is in concordance with other authors' suggestions that presence of WS serves as an anti-predator shield for co-breeding passerines (e.g., Indykiewicz 2006). It may be also explained in terms of differing construction structure of occupied vs unoccupied nests. Nests regularly occupied by WS pairs have more space between twigs, and there are many niches in the upper part enabling nest building by co-breeding passerines. In contrast, WS nests unoccupied for several years have no niches and are more compressed, which constrains penetration by passerines. However, it has been shown that even abandoned WS nests may still constitute attractive nesting site for one to two pairs of Tree Sparrow and House Sparrow (Boratyn 2015).

Among models investigating both presence and number of pairs of a particular species, the House Sparrow models were characterized by the highest predictive capability. For both presence and number of pairs, habitat type, distance to the nearest building, and presence of co-breeding passerines were recognized as important factors. House Sparrows preferred to breed within WS nests situated on electricity poles, surrounded mainly by arable land, situated closer to buildings, and without cobreeding passerines, especially the Tree Sparrow. Building nests on electricity poles has several advantages both for the nest owner and for the co-breeding species. Such locations increase protection against mammalian predators, e.g., Martens Martes sp. This advantage has been postulated as the main reason of changes in nest locations in WS during the last 40 years in W Poland (Tryjanowski et al. 2009). However, such exposed locations may increase the risk of being predated (e.g., Tobolka 2007) and do not protect the nest owners' nestlings (and probably also co-breeding species) against severe weather conditions (e.g., Moreno and Møller 2011; Janiszewski et al. 2015; Tobolka et al. 2015).

We recognized prevalence of arable lands in close proximity of WS nests as another important predictor of House Sparrow breeding. Preference for nesting in WS nests located in areas with high prevalence of arable land was surprising because often farmland bird species abundance decreases with increasing area of arable land (Donald et al. 2001). However, the direction of this relationship may depend on the availability of that habitat at the regional scale-for example, some regions of Britain scarce in arable habitat are characterized by increased bird numbers (Robinson et al. 2001). In our study area, arable land is less common than meadows, pastures, or forests. In traditionally cultivated, organic agricultural farmland of NE Poland, with a low rate of herbicide use (Adamczewski and Dobrzański 2012), arable land serves as attractive foraging habitat for Sparrows. Meadow and pastures are less attractive, because vegetation there is usually lower, and plants are not allowed to produce fruits due to regular grazing or mowing. Although Sparrows need invertebrates during the breeding season for feeding young nestlings, they need plant seeds to feed themselves and older nestlings 
Table 4 Rank of the best OLS regression models for factors affecting number of species and pairs breeding within White Storks nests in NE Poland based on Akaike's information criterion corrected for small sample size $\left(\mathrm{AIC}_{\mathrm{c}}\right)$

\begin{tabular}{|c|c|c|c|c|c|c|}
\hline $\begin{array}{l}\text { Model } \\
\text { type }\end{array}$ & Model parameters & $\mathrm{AIC}_{\mathrm{c}}$ & $\Delta \mathrm{AIC}_{\mathrm{c}}$ & $\begin{array}{l}\text { Akaike's } \\
\text { weights }\end{array}$ & $\begin{array}{l}\text { Wald } \\
\text { test }(p)\end{array}$ & $\begin{array}{l}\text { Adj. } \\
R^{2}\end{array}$ \\
\hline FM & \multicolumn{6}{|c|}{ NoSpec $\sim$ arab + mead + pole + WSPres + DisBuild + NestThick + DisClosWS } \\
\hline \multirow[t]{3}{*}{ BMs } & Int & 283.1 & 0 & 0.266 & $<0.001$ & - \\
\hline & Int - DisBuild + pole & 283.9 & 0.86 & 0.173 & $<0.001$ & 0.01 \\
\hline & Int + pole & 284 & 0.93 & 0.167 & $<0.001$ & 0.001 \\
\hline FM & \multicolumn{6}{|l|}{$\begin{array}{l}\text { TotNoPair } \sim \text { arab }+ \text { mead }+ \text { pole }+ \\
\text { WSPres }+ \text { DisBuild }+ \text { NestThick }+ \\
\text { DisClosWS }\end{array}$} \\
\hline BMs & - Int + arab + NestThick - DisBuild + pole & 524.6 & 0 & 0.378 & $<0.001$ & 0.107 \\
\hline FM & \multicolumn{6}{|c|}{ SPair1 $\sim$ arab + mead + pole + WSPres + DisBuild + NestThick + NestSit + DisClosWS + SAlien } \\
\hline \multirow[t]{3}{*}{$\mathrm{BMs}$} & - Int + NestThick - SAlien & 272.3 & 0 & 0.238 & $<0.001$ & 0.099 \\
\hline & - Int + NestThick + DisClosWS - SAlien & 272.5 & 0.24 & 0.211 & $<0.001$ & 0.105 \\
\hline & $\begin{array}{l}- \text { Int }+ \text { NestThick }- \text { mead }+ \\
\text { DisClosWS }- \text { SAlien }\end{array}$ & 273 & 0.73 & 0.165 & $<0.001$ & 0.11 \\
\hline FM & \multicolumn{6}{|c|}{$\begin{array}{l}\text { SPair } 2 \sim \text { arab }+ \text { mead }+ \text { pole }+ \text { WSPres }+ \text { DisBuild }+ \text { NestThick }+ \text { NestSit }+ \text { DisClosWS + } \\
\text { HSPres + TSPres }\end{array}$} \\
\hline \multirow[t]{2}{*}{ BMs } & - Int + NestThick & 280.9 & 0 & 0.237 & $<0.001$ & 0.031 \\
\hline & - Int + NestThick + pole & 281.6 & 0.68 & 0.169 & $<0.001$ & 0.034 \\
\hline FM & \multicolumn{6}{|c|}{$\begin{array}{l}\text { HSPair1 } \sim \text { arab + mead + pole + WSPres + DisBuild + NestThick + NestSit + DisClosWS + } \\
\text { HSAlien }\end{array}$} \\
\hline $\mathrm{BMs}$ & $\begin{array}{l}\text { Int }+ \text { arab }- \text { mead }- \text { DisBuild }- \text { HSAlien }+ \\
\text { pole }\end{array}$ & 437.1 & 0 & 0.428 & $<0.001$ & 0.133 \\
\hline FM & $\begin{array}{l}\text { HSPair } 2 \sim \text { arab }+ \text { mead }+ \text { pole }+ \text { WSPres }+ \\
\quad \text { SPres }+ \text { TSPres }\end{array}$ & aild +1 & tThicl & NestSit + & ClosWS + & \\
\hline \multirow[t]{2}{*}{$\mathrm{BMs}$} & $\begin{array}{l}\text { Int }+ \text { arab }- \text { mead }- \text { DisBuild }- \text { TSPres }+ \\
\text { pole }\end{array}$ & 434.8 & 0 & 0.252 & $<0.001$ & 0.148 \\
\hline & Int + arab - DisBuild - TSPres + pole & 435.4 & 0.58 & 0.188 & $<0.001$ & 0.137 \\
\hline FM & \multicolumn{6}{|l|}{$\begin{array}{l}\text { TSPair1 } \sim \text { arab }+ \text { mead }+ \text { pole }+ \text { WSPres }+ \\
\text { DisBuild + NestThick + NestSit }+ \\
\text { DisClosWS + TSAlien }\end{array}$} \\
\hline \multirow[t]{2}{*}{ BMs } & $\begin{array}{l}- \text { Int }+ \text { NestThick }+ \text { arab }+ \\
\text { mead }- \text { TSAlien }+ \text { pole }\end{array}$ & 409.4 & 0 & 0.205 & $<0.001$ & 0.081 \\
\hline & - Int + NestThick + arab + mead - TSAlien & 409.5 & 0.09 & 0.196 & $<0.001$ & 0.088 \\
\hline FM & \multicolumn{6}{|c|}{$\begin{array}{l}\text { TSPair } 2 \sim \text { arab }+ \text { mead }+ \text { pole }+ \text { WSPres }+ \text { DisBuild }+ \text { NestThick + NestSit + DisClosWS + } \\
\text { SPres + TSPres }\end{array}$} \\
\hline \multirow[t]{3}{*}{$\mathrm{BMs}$} & - Int + arab + mead + NestThick & 409.5 & 0 & 0.24 & $<0.001$ & 0.072 \\
\hline & - Int + arab + mead + NestThick + pole & 409.7 & 0.11 & 0.228 & $<0.001$ & 0.079 \\
\hline & - Int + arab + mead + NestThick - HSPres & 410.4 & 0.85 & 0.157 & $<0.001$ & 0.074 \\
\hline
\end{tabular}

Only the best models with $\triangle \mathrm{AIC}_{\mathrm{c}} \leq 1$ are presented; Akaike's weights are calculated from the full set of models. Adj $R^{2}$ —adjusted coefficient of determination (values $>0.10$ bolded). Predictor codes: see Table 1

$F M$ full model, BMs best models, Int intercept
(Anderson 2006). Farms provide other sources of food: in more traditionally managed farms, which dominate in our study area, animals are kept outside the buildings, hence the food for them is also available for birds, in this case for Sparrows. In WS nests located in or in close proximity to traditional farms, the number of nesting House Sparrows was higher compared to those breeding close to modern farms (Kosicki et al. 2007). The significant preference of House Sparrows to locate their nests in WS nests on electricity poles and closer to buildings has been also reported from northcentral Poland (Indykiewicz 2006).

\section{Inter-specific competition}

Finally, we found that the House Sparrow was more often recorded in WS nests without breeding Tree Sparrows. This relationship may result from high inter-species competition. Firstly, the House Sparrow is a little bigger than the Tree Sparrow (Cramp 1998) and known for aggressive behavior and high territoriality during breeding (e.g., Gowaty 1984; Wingfield et al. 1987), which has not been reported for Tree Sparrow (Cordero and Senar 1990). Secondly, the House Sparrow is a very flexible nester, nesting in many different 
Table 5 The best OLS regression models for factors affecting number of species and pairs breeding within White Storks nests in NE Poland

\begin{tabular}{|c|c|c|c|}
\hline \multicolumn{4}{|c|}{ All pairs combined (TotNoPair, model1, adj. $R^{2}=0.107$ ) } \\
\hline Int & -1.81 & 1.56 & 0.249 \\
\hline Arab & 1.44 & 0.56 & 0.011 \\
\hline Pole & 1.74 & 0.65 & 0.008 \\
\hline DisBuild & -0.25 & 0.11 & 0.031 \\
\hline NestThick & 0.91 & 0.39 & 0.020 \\
\hline \multicolumn{4}{|c|}{ Starling1 (SPair, model3, adj. $R^{2}=0.110$ ) } \\
\hline Int & -0.76 & 0.66 & 0.258 \\
\hline Mead & -0.24 & 0.19 & 0.200 \\
\hline NestThick & 0.40 & 0.15 & 0.009 \\
\hline SAlien & -0.86 & 0.26 & 0.001 \\
\hline DisClosWS & 0.10 & 0.06 & 0.090 \\
\hline \multicolumn{4}{|c|}{ House Sparrow1 (HSPair, model1, adj. $R^{2}=0.133$ ) } \\
\hline Int & 1.33 & 0.38 & 0.001 \\
\hline Habit & 0.87 & 0.40 & 0.032 \\
\hline DisBuild & -0.64 & 0.33 & 0.052 \\
\hline HSAlien & -0.19 & 0.08 & 0.021 \\
\hline Pole & -0.69 & 0.26 & 0.008 \\
\hline \multicolumn{4}{|c|}{ House Sparrow2 (HSPair, model 1, adj. $R^{2}=0.148$ ) } \\
\hline Int & 1.28 & 0.36 & 0.001 \\
\hline Arab & 0.91 & 0.40 & 0.025 \\
\hline Past & -0.54 & 0.33 & 0.102 \\
\hline DisBuild & -0.19 & 0.08 & 0.022 \\
\hline Pole & 0.92 & 0.46 & 0.049 \\
\hline TSPres & -0.69 & 0.22 & 0.003 \\
\hline
\end{tabular}

Predictor codes: see Table 1

Int intercept

locations including apertures and holes in buildings but also on antennas or bushes (Cramp 1998). Therefore, it can occupy more sites in WS nests and prevent nesting of other species. House and Tree Sparrows have similar habitat preferences; therefore, they compete for food and nest sites in areas of sympatric occurrence, especially in areas with domination of the latter species (Cordero and Rodriguez-Teijeiro 1990; Summers-Smith 1995). This may explain avoidance of cobreeding by both sparrow species in WS nests revealed in our study. The number of breeding Starlings was also higher in WS nests without presence of other passerines. This might also be explained in terms of inter-species competition or different nest site preferences.

\section{Other potential factors}

Low predictive capabilities of many of the presented logistic regression models and low determination coefficients in OLS regression models suggest that there are more unstudied factors affecting the number of pairs of particular species breeding within WS nests. For the House Sparrow, it may be the number of predators in the area. In Poland, free-ranging domestic cats Felis domesticus hunt ca. one bird per cat per month, mostly Sparrow, and the real number of predated birds is predicted to be much higher. The highest predation occurs in June when juvenile Sparrows leave the nests (Baker et al. 2005; Krauze-Gryz et al. 2016). In British villages, the domestic cat is a major House Sparrow predator responsible for up to $30 \%$ of its mortality (Churcher and Lawton 1987). Hence, the number of cats in the area may affect the decision about breeding within WS nests. The number of another predator, the Sparrowhawk, may also serve as an important factor affecting the decision on breeding within WS nests. The population of this avian raptor increased 13 -fold during the last 30 years in the study area (Pugacewicz 2010). Summers-Smith (2005) suggested that increasing Sparrowhawk predation, added to that from domestic and feral cats, may pose a serious threat to the House Sparrow population. Moreover, the availability of other potential nesting sites (buildings, hollow trees, haystacks, etc.) may be a significant factor determining sparrow presence in WS nest (e.g., Indykiewicz 1991).

\section{Conclusions}

Our study revealed that $>50 \%$ of studied WS nests in NE Poland contained co-breeding passerines. We recognized nest location, distance to the nearest building, arable land prevalence, and presence of other co-breeding passerines as the main determinants of passerine nesting within WS nests in NE Poland. Breeding in WS nests is favorable for passerines as they provide an anti-predatory shield and a well-insulated nesting site. Further studies comparing breeding success in nests within or outside a WS nest are needed to fully comprehend the advantages and disadvantages of breeding in WS nests.

We are aware that our limited dataset (based on a restricted number of predictors) is insufficient for a comprehensive investigation of factors affecting breeding of passerines in WS nests. The data presented here can, however, be treated as a pilot study contributing to the planning of a broad-scaled investigation including local populations of passerine species that may nest in White Stork nests. The question of intraspecies competition for nesting within WS nests should be addressed in future studies.

Acknowledgments We would like to thank Jarosław Banach, Aneta Gajko, Edyta Kapowicz, Łukasz Krajewski, Krzysztof Sokołowski, Anna Suchowolec and Małgorzata Zbyryt for help in the field. We are also grateful to Nicola F. Reeve, from the University of Leicester, for assistance with English Language Editing.

Open Access This article is distributed under the terms of the Creative Commons Attribution 4.0 International License (http:// creativecommons.org/licenses/by/4.0/), which permits unrestricted use, distribution, and reproduction in any medium, provided you give 
appropriate credit to the original author(s) and the source, provide a link to the Creative Commons license, and indicate if changes were made.

\section{References}

Adamczewski K, Dobrzański A (2012) Future for weed sciences in changing agriculture. Prog Plant Prot 52:867-878

Anderson TR (2006) Biology of the ubiquitous house sparrow: from genes to populations. Oxford University Press, Oxford

Baker PJ, Bentley AJ, Ansell RJ, Harris S (2005) Impact of predation by domestic cats Felis catus in an urban area. Mammal Rev 35:302312. doi:10.1111/j.1365-2907.2005.00071.x

Bartoń K (2013) MuMIn: multi-model inference. R package version 1.10.0, http://CRAN.R-project.org/package=MuMIn

Bocheński M (2005) Nesting of the sparrows Passer spp. in the white stork Ciconia ciconia nests in a stork colony in Kłopot (W Poland). Int Stud Sparrows 30:39-41

Boratyn A (2015) The selectivity of nest site White Storks Ciconia ciconia in the district Nakło [in Polish], Master Thesis. University of Science and Technology in Bydgoszcz

Burnham KP, Anderson DR (2002) Model selection and multi-model inference: a practical information-theoretic approach. Springer, New York

Chenchouni H (2016) Variation in white stork (Ciconia ciconia) diet along a climatic gradient and across rural-to-urban landscapes in North Africa. Int J Biometeorol. doi:10.1007/s00484-016-1232-x

Churcher PB, Lawton JH (1987) Predation by domestic cats in an English village. J Zool 212:439-455

Chylarecki P, Jawińska D (2007) Common breeding birds monitoring in Poland: annual report 2005-2006. Polish Society for the Protection of Birds, Warszawa

Chylarecki P, Jawińska D, Kuczyński L (2006) Common breeding birds monitoring in Poland: annual report 2003-2004. Polish Society for the Protection of Birds, Warszawa

Cordero PJ, Rodriguez-Teijeiro JD (1990) Spatial segregation and interaction between house sparrows and tree sparrows (Passer spp.) in relation to nest site. Ekol Pol 38:443-452

Cordero PJ, Senar JC (1990) Interspecific nest defense in European sparrows: different strategies to deal with a different species of opponent? Ornis Scand 21:71-73

Cramp S (1998) The complete birds of the Western Palearctic on CDROM. In Optimedia. Oxford University Press, Oxford

Crick HQP, Robinson RA, Appleton GF, Clark NA, Rickard AD (Eds) (2002). Investigation into the causes of the decline of starlings and house sparrows in Great Britain. BTO Res Rep 290, The Nunnery, Thetford, Norfolk

Donald PF, Green RE, Heath MF (2001) Agricultural intensification and the collapse of Europe's farmland bird populations. Proc R Soc Lond B 268:25-29. doi:10.1098/rspb.2000.1325

Elgar MA (1989) Predator vigilance and group size in mammals and birds: a critical review of the empirical evidence. Biol Rev 64:13-33

Gill FB (2007) Ornithology. W.H. Freeman and Company, New York

Gowaty PA (1984) House sparrows kill eastern bluebirds. J Field Ornithol 55:378-380

Guziak R, Jakubiec Z (2006) White Stork Ciconia ciconia (L.) in Poland in 2004. Results of the VIth International White Stork Census. PTPP ,pro Natura", Wrocław

Hegyi G, Garamszegi LZ (2011) Using information theory as a substitute for stepwise regression in ecology and behavior. Behav Ecol Sociobiol 65:69-76. doi:10.1007/s00265-010-1036-7

Hole DG, Whittingham MJ, Bradbury RB, Anderson GQA, Lee PLM, Wilson JD, Krebs JR (2002) Widespread local house-sparrow extinctions. Nature 418:913-932
Hosmer DW, Lemeshow S, Sturdivant RX (2013) Applied logistic regression. Wiley, Hoboken

Indykiewicz P (1991) Nest and nest-sites of the house sparrow Passer domesticus (LINNAEUS, 1975) in urban, suburban and rural environments. Acta Zool Cracov 34:475-495

Indykiewicz P (1998) Breeding of house sparrows Passer domesticus, tree sparrows Passer montanus and starling Sturnus vulgaris in the white stork Ciconia ciconia nests. Not Ornit 39:97-104

Indykiewicz P (2006) House sparrow Passer domesticus, Starling Sturnus vulgaris, tree sparrow Passer montanus and other residents of the white stork Ciconia ciconia. In: Tryjanowski P, Sparks TH, Jerzak L (eds) The white stork in Poland: studies in biology, ecology and conservation. Bogucki Wyd. Naukowe, Poznan, pp 225-235

Jaksić FM, Braker HE (1983) Food-niche relationships and guild structure of diurnal birds of prey: competition versus opportunism. Can $\mathrm{J}$ Zool 61:2230-2241

Janiszewski T, Minias P, Wojciechowski Z (2015) Selective forces responsible for transition to nesting on electricity poles in the white stork Ciconia ciconia. Ardea 103:39-50

Jungwirth A, Josi D, Walker J, Taborsky M (2015) Benefits of coloniality: communal defence saves anti-predator effort in cooperative breeders. Funct Ecol 29:1218-1224

Kondracki J (2013) Geografia regionalna Polski. Wyd Nauk PWN, Warszawa

Kosicki JZ, Profus P, Dolata PT, Tobółka M (2006) Food composition and energy demand of the white stork Ciconia ciconia breeding population. Literature survey and preliminary results from Poland. In: Tryjanowski P, Sparks TH, Jerzak L (eds) The white stork in Poland: studies in biology, ecology and conservation. Bogucki Wyd. Naukowe, Poznań, pp 169-183

Kosicki JZ, Sparks TH, Tryjanowski P (2007) House sparrows benefit from the conservation of white storks. Naturwissenschaften 94:412-415

Koskimies J (1957) Terns and gulls as features of habitat recognition for birds nesting in their colonies. Ornis Fenn 34:1-6

Krauze-Gryz D, Żmihorski M, Gryz J (2016) Annual variation in prey composition of domestic cats in rural and urban environment. Urban Ecosyst. doi:10.1007/s11252-016-0634-1

Lesnoff M, Lancelot R (2012) aod: analysis of overdispersed data. R package version 1.3, http://cran.r-project.org/package=aod

Mitschke A, Rathje H, Baumung S (2000) House sparrows in Hamburg: population, habitat choice and threats. Hamb Avifaunist Beitr 30: 129-204

Møller AP (1987) Advantages and disadvantages of coloniality in the swallow, Hirundo rustica. Anim Behav 35:819-832

Moreno J, Møller AP (2011) Extreme climatic events in relation to global change and their impact on life histories. Curr Zool 57:375-389

Nicol CJ, Gregory NG, Knowles TG, Parkman ID, Wilkins LJ (1999) Differential effects of increased stocking density, mediated by increased flock size, on feather pecking and aggression in laying hens. Appl Anim Behav Sci 65:137-152

Pearce JL, Ferrier S (2000) Evaluating the predictive performance of habitat models developed using logistic regression. Ecol Model 133:225-245

Pinowski J, Haman A, Jerzak L, Pinowska B, Barkowska M, Grodzki A, Haman K (2006) The thermal properties of some nests of the Eurasian tree sparrow Passer montanus. J Therm Biol 31:573581. doi:10.1016/j.jtherbio.2006.05.007

Profus P (2006) Population changes and breeding ecology of the white stork Ciconia ciconia L. in Poland against a background of the European population. Synthesis. Stud Nat 50:1-155

Pugacewicz E (2010) Szponiaste Falconiformes krajobrazu rolniczoleśnego południowej części Wysoczyzny Białostockiej. Dubelt 2: $65-82$

Quinn JL, Ueta M (2008) Protective nesting associations in birds. Ibis $150: 146-167$ 
R Development Core Team (2015) R: a language and environment for statistical computing. R foundation for statistical computing, Vienna. http://www.R- project.org

Richner H, Heeb P (1995) Communal life: honest signaling and the recruitment center hypothesis. Behav Ecol:7115-7119

Robin X, Turck N, Hainard A, Tiberti N, Lisacek F, Sanchez J-C, Müller M (2011) PROC: an open-source package for R and S + to analyze and compare ROC curves. BMC Bioinform 12:1-8. doi:10.1186/1471-2105-12-77

Robinson RA, Wilson JD, Crick HQ (2001) The importance of arable habitat for farmland birds in grassland landscapes. J Appl Ecol 38: 1059-1069. doi:10.1046/j.1365-2664.2001.00654.x

Robinson RA, Siriwardena GM, Crick HQP (2005) Size and trends of house sparrow Passer domesticus. Ibis 147:552-562. doi:10.1111/j. 1474-919x.2005.00427.x

Saino N (1994) Time budget variation in relation to flock size in carrion crows, Corvus corone corone. Anim Behav 47:1189-1196

Shaw LM, Chamberlain D, Evans M (2008) The house sparrow Passer domesticus in urban areas: reviewing a possible link between postdecline distribution and human socioeconomic status. J Ornithol 149:293-299

Statistical Office (2016) Agriculture in Podlaskie Voivodship in 2015. Statistical information and elaborations. Statistical Office in Białystok, Białystok

Stenhouse IJ, Gilchrist HG, Montevecchi WA (2005) An experimental study examining the anti-predator behaviour of Sabine's gulls (Xema sabini) during breeding. J Ethol 23:103-108

Summers-Smith JD (1995) The tree sparrow. Bath Press, Bath
Summers-Smith JD (2003) The decline of the house sparrow: a review. $\mathrm{Br}$ Birds 96:439-446

Summers-Smith JD (2005) Changes in the house sparrow population in Britain. Intern Stud Sparrows 30:24-37

Tobolka M (2007) Sparrow hawk Accipiter nisus attacks sparrows Passer $s p$. roosting in white stork nests. Intern. Stud Sparrows 32:39-41

Tobolka M (2011) Roosting of tree sparrow (Passer montanus) and house sparrow (Passer domesticus) in white stork (Ciconia ciconia) nests during winter. Turk J Zool 35:879-882. doi:10.3906/zoo-1003-106

Tobolka M, Zolnierowicz KM, Reeve NF (2015) The effect of extreme weather events on breeding parameters of the white stork Ciconia ciconia. Bird Study 62:377-385. doi:10.1080/ 00063657.2015.1058745

Tryjanowski P, Kosicki JZ, Kuźniak S, Sparks TH (2009) Long-term changes and breeding success in relation to nesting structures used by the white stork, Ciconia Ciconia. Ann Zool Fenn 46:34-38

Valera F, Casas-Crivillé A, Hoi H (2003) Interspecific parasite exchange in a mixed colony of birds. J Parasito 89:245-250. doi: 10.1645/0022-3395(2003)089[0245:IPEIAM]2.0.CO;2

Wegrzynowicz A (2012) The use of nest-boxes by two species of sparrows (Passer domesticus and P. montanus) with opposite trends of abundance - the study in Warsaw. Intern Stud Sparrows 36:18-29. doi:10.1515/isspar-2015-0011

Wheelwright NT, Lawler JJ, Weinstein JH (1997) Nest-site selection in savannah sparrows: using gulls as scarecrows? Anim Behav 53: 197-208

Wingfield JC, Ball GF, Dufty AM, Hegner RE, Ramenofsky M (1987) Testosterone and aggression in birds. Am Sci 75:602-608 